\title{
The "Golden Shale": An indicator of coastal stability for Marble Point, McMurdo Sound, over the last four million years
}

\author{
G. G. C. Claridge and I. B. Campbell \\ Land and Soil Consultancy Services, 23 Viewmount, Nelson, New Zealand
}

\begin{abstract}
A small sedimentary deposit near Gneiss Point on the western side of McMurdo Sound, previously identified as shale, is described. The deposit is phillipsite, a zeolite that is believed to have formed from the deposition and alteration of volcanic ash in a small ice-marginal saline lake. Other previously recorded occurrences of phillipsite in the dry valleys are believed to be several million years old. A similar age for this deposit is suggested for the Gneiss Point deposit. This is consistent with other weathering and landscape features found in the immediate area, including traces of halloysite in soils. The deposit is very close to sea level but could not have formed if the site had been below sea level, indicating that there has been very little uplift following that which caused the sea to retreat from the Wright Fiord.
\end{abstract}

Citation: Claridge, G.C.G. and Campbell, I.D., The "Golden Shale": An indicator of coastal stability for Marble Point, McMurdo Sound, over the last four million years, in Antarctica: A Keystone in a Changing World - Online Proceedings of the 10th ISAES, edited by A.K. Cooper and C.R. Raymond et al., USGS Open-File Report 2007-1047, Short Research Paper 087, 4 p.; doi:10.3133/of2007-1047.srp087

\section{Introduction}

Between Cape Bernacchi and Gneiss Point on the western side of McMurdo Sound, a strip of land, a few kilometres wide, is exposed by retreat of ice from McMurdo Sound and the Wilson Piedmont Glacier (Fig. 1). To the south it merges with the ice-free Taylor Valley, In the mouth of the valley and around Cape Bernacchi the surface is covered with tills of Ross I age (Hall et al.., 2000), but further north, towards Marble Point and Gneiss Point, the tills become patchy and basement rocks are exposed. The whole region is presumed to have become ice-free by retreat of the Wilson Piedmont Glacier, a remnant of a greatly expanded Ross Ice Shelf which covered the area during the Last Glacial Maximum leaving a well defined trim line sloping into Taylor Valley. The ice left the area around 6000 years ago.

The east coast of the region has a coastal plain at an elevation of around $50-70 \mathrm{~m}$ above sea level. On this plain around two km west of Gneiss Point yellow shaly material is exposed over an area of $\sim 10 \mathrm{ha}$, and is the subject of this report.

\section{Geology of Marble Point area}

The geology of the Marble Point area consists of granites, granodiorites, marbles and schists of the pre-Cambrian to early Palaeozoic Ross Supergroup basement complex (Gunn and Warren, 1962). The oldest rocks, the marbles, are coarse-grained, granular and stained with iron oxides. When exposed, the surface is loose and crumbly. Coarse and fine-grained schists are interbedded with the marbles. The schist is dark-coloured and soft or only moderately hard. It is in some places massive and in others occurs as thin bands within the marble It is often weathered or altered to a soft powdery micaceous silt, commonly dark green in colour but in places red. Harder, massive gneissic rocks are found in the area and are particularly well-exposed in the cliffs around Gneiss Point.

The granodiorites are generally grey and fine to medium

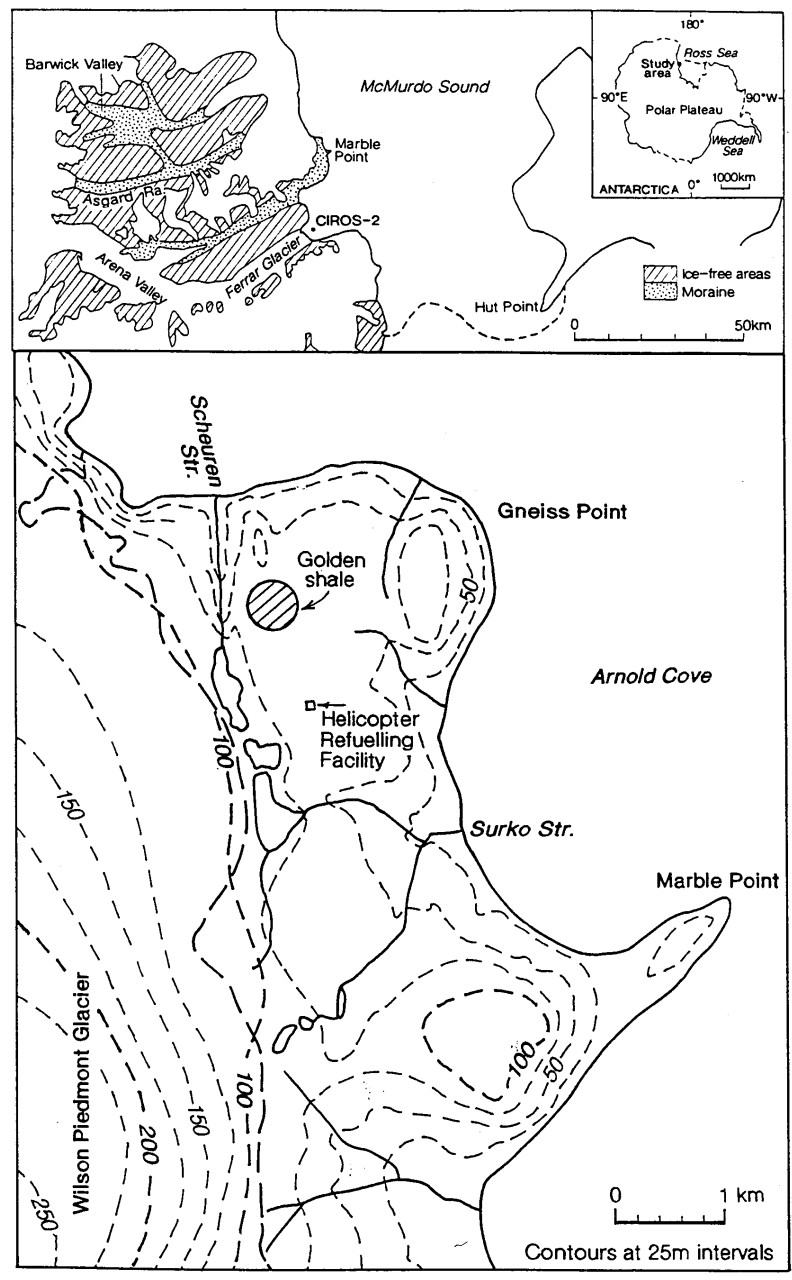

Figure 1. Map of the McMurdo Dry Valleys (upper) and the coastal area around Marble Point (lower), showing the approximate area underlain by the Golden Shale deposit. 
grained. In places they are stained and crumbled, Iron-containing minerals, such as biotite are often oxidised, appearing as rusty brown patches on the granodiorite surface, and in places, where iron-containing minerals are abundant, the granodiorite may be loose and granular or only weakly coherent, to a depth of several centimetres. The weathering of the granodiorites was discussed in detail by Kelly and Zumberge (1961) A massive intrusion of Ferrar Dolerite (Harrington, 1958) crops out in the northern part of the area, where it forms cliffs with prominent columnar jointing and a prominent peak on the edge of the Bay of Sails.

\section{"Golden Shale"}

Immediately south of the outcrop of Ferrar Dolerite a small deposit, approximately $6 \mathrm{~m}$ thick, of yellow, poorly consolidated shale-like material covers an area of approximately 10 ha. It appears to be flat-lying, in that the upper surface is more or less horizontal. The base of the material is not visible as the slopes surrounding the outcrop are covered with loose till or drift containing fragments of the material (Fig. 2).

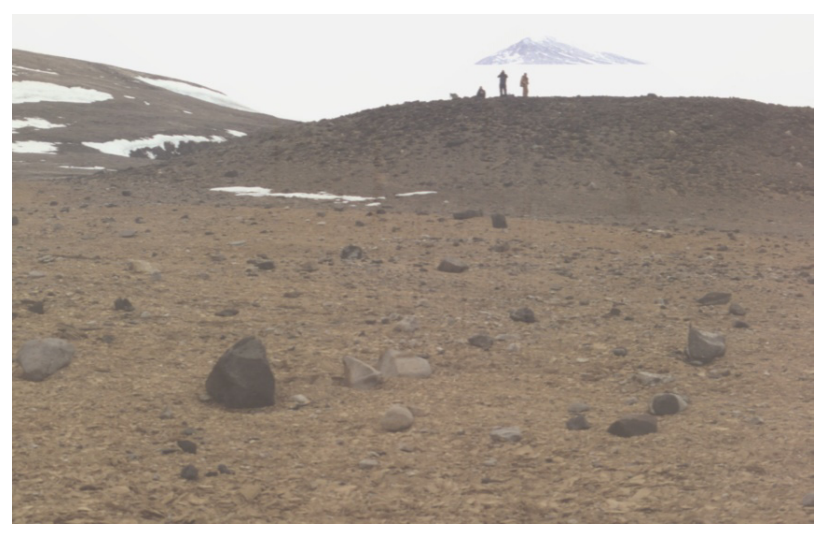

Figure 2. View north over the Golden Shale deposit.

To the east, where slopes are gentler, fragments of it can be found a considerable distance from the outcrop. The material is intensely fractured and the surface of the outcrop consists of pebble-sized, platy fragments, commonly lying sub-vertically with micro-polygonal frost sorting patterns. The surface of the deposit is soft and spongy.

The material is bedded, with pale brown to brownish yellow (10YR 6/6-7/4) layers $10-15 \mathrm{~mm}$ thick separated by pale yellow $(2.5 \mathrm{Y} 8 / 4)$ layers about $0.25-0.5 \mathrm{~mm}$ thick. (Fig. $3)$. In hand specimen the laminae do not appear to be graded. On its northern end, the shale deposit abuts the dolerite peak and outcrop but does not extend below it. Scattered dolerite and other erratics lie on the surface of the shale outcrop indicating that it is at least older than the Last Glacial Maximum. This material was described as shale and termed the "Golden Shale" in one of the first reports of the geology of the Marble point area (Metcalf and Eddy, 1958).

Claridge and Campbell (in press) showed by a combination of x-ray diffraction, chemical analyses and scanning electron microscopy data that the Golden Shale is comprised almost entirely of the zeolite phillipsite, with very few traces of any other material. They considered that the deposit originated from the accumulation of volcanic ash in an ice-marginal lake similar to Lake Joyce in the upper Taylor Valley or Lake Wilson near the Darwin Glacier. Both these lakes are thermally and chemically stratified, with relatively dense saline bottom waters, which are warmed by trapped solar radiation. In this case the lake would be marginal between the land and an enlarged Ross Ice Shelf, indicating that the lake existed at a time of low sea level during a glacial maximum. The complete alteration of the ash to zeolite, with no residue of glass or other minerals present probably indicate that the lake was thermally stratified with bottom temperatures possibly as high as the $25^{\circ} \mathrm{C}$ currently found for the bottom waters of Lake Vanda (Shirtcliffe, 1965), Lake Joyce, in the upper Taylor Glacier region (Shacat et al., 2004) and Lake Wilson, near the Darwin Glacier (Webster et al., 1997) are possible analogues.

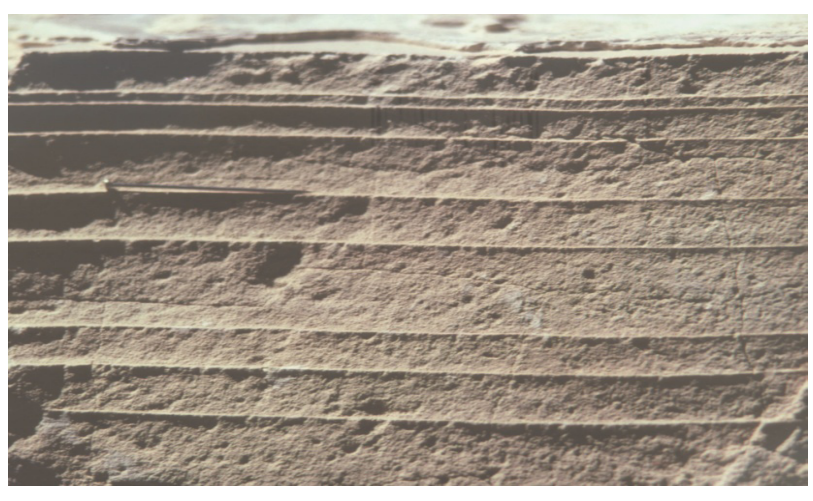

Figure 3. Detail of a Golden Shale exposure, showing stratification. Pin is $2.5 \mathrm{~cm}$ long.

\section{Discussion}

Authigenic phillipsite is found in deep-sea sediments, where it forms at low temperatures and high pressures (Goldberg and Arrhenius, 1958), but is more commonly formed by the alteration of volcanic glass that has fallen in saline alkaline lakes, mainly in semi-arid regions (Hay, 1964). Mariner and Surdam (1970) showed that the solubility of rhyolitic glass increases with increasing alkalinity, whereas the ratio of silicon to aluminium decreases. They considered that the strong correlation observed between alkalinity and zeolite mineralogy in saline alkaline lakes was a function of this relationship between $\mathrm{pH}$ and the Si/Al ratio. Only a single zeolite would be expected to form in any given conditions, since each has a limited and distinct stability field. For phillipsite to form, the $\mathrm{pH}$ must 
have been $>9$, with a high proportion of sodium in the salts in solution in the lake water, and a low $\mathrm{Si} / \mathrm{Al}$ ratio in the weathering glass. Zeolites are also formed in weathering tuffs and vitric ashes where these conditions prevail.

Linkletter (1974) found phillipsite at two sites in the Taylor Valley, one on the Rhone Bench at an altitude of $1100 \mathrm{~m}$ and the other lower down on the south side of the valley near Nussbaum Riegel, at an altitude of $800 \mathrm{~m}$. These deposits were thin and in material which appeared to be lacustrine sediments, covered by tills which, if the chronology of Taylor valley glaciations (Hall et al., 2000) is accepted, are several million years old, judging by their state of weathering. The occurrences of phillipsite described by Linkletter (1974) were attributed to the weathering of volcanic ash, either from a local source or from a widespread regional event, which fell in a saline pond, such as those which are frequently found in the ice-free areas. Claridge and Campbell (1974) found vesicular glass fragments in the sand fraction and halloysite in the clay fraction of many old soils of the Taylor Valley, which were also attributed to an ash fall.

No shards of glass were found in the fragments of Golden Shale examined, and the material is almost entirely zeolite (phillipsite). The deposit is layered, with bands nearly always parallel, but varying in thickness from 1.5 to greater than $10 \mathrm{~mm}$. One sample had 14 bands over $10 \mathrm{~cm}$ of rock thickness. If the bands are seasonal, perhaps indicating rapid formation of zeolite during a warm summer period and slow formation or settling during periods when the lake was ice-covered, then the layers cover a time span of up to 20,000 years, indicating perhaps a slow accumulation of ash.

Ash falls are, however, generally events of short duration, leading to the rapid deposition of thick layers of ash. If the ash had fallen on the landscape surrounding a saline lake and small portions washed in annually the zeolite deposit would be expected to contain appreciable numbers of sand grains or other materials derived from the land surface, but no significant sand grains or rock particles were observed. It is more likely that the layers are diurnal, probably related to the presence of a thin ice cover on the lake during the night, and that the deposit formed over a period of months, rather than years

In recent years several deposits of volcanic ash have been reported in the McMurdo Sound area. Barrett et al. (1992) reported a thin ash layer from drill core $125 \mathrm{~m}$ below the sea floor off the terminus of the Ferrar Glacier. Their best age for this ash was $3 \pm 0.4 \mathrm{Ma}$. A layer of ash overlying colluvium and overlain by drift deposited by the Wright Lower Glacier was found by Hall et al. (1993) near the snout of the Hart Glacier in the Wright Valley. The ash fell $3.9 \pm$ $0.3 \mathrm{Ma}$ ago. Older ash layers, ranging from $4.33 \pm 0.07$ to $15.24 \pm 0.08 \mathrm{Ma}$ in age have been found in the Quartermain Range (Marchant et al., 1993a) and in the Asgard Range (Marchant et al., 1993b). These ashes were considered to have originated from Mt Discovery or Mt Morning, about
$100 \mathrm{~km}$ south of Marble Point. No younger ashes have been recorded in the McMurdo Dry Valleys. We therefore consider that the ash shower that gave rise to the Golden Shale was erupted more than three million years ago. Since the Hart Ash is only $10 \mathrm{~cm}$ thick where it is found in tills, the Golden Shale must represent the concentration of ash falling into a lake covering at least 60 times the area of the shale deposit.

About $1 \mathrm{~km}$ to the south of the Golden Shale outcrop we have found old, fine-textured, strongly-coloured soils that contain both glass fragments and halloysite (Campbell et al., 1992). We consider these to be weathering products of an old ash shower that blanketed the area. The degree of weathering of these surface rocks is far greater than would be expected for material deposited or exposed by the last advance of the Ross Ice Shelf, the Ross 1 episode, on which soils of weathering stage 1 (Campbell and Claridge, 1975) are usually found. The degree of weathering of these rocks, and the deeply weathered and stained soils containing halloysite, indicates that they are of weathering stage 4 or 5 , with an age of greater than 3.5 million years. The implication is that the surface has survived through the ice advances and retreats of the last 3.5 million years or more without being planed or eroded. The effect of these glacial advances has only been to deposit thin tills on places on this surface.

Because the shale is fractured and highly susceptible to erosion it would not survive wave action However it could be expected to survive the expansion and retreat of cold-based ice like that of the Wilson Piedmont Glacier today.

\section{Implications for geological history of Marble Point area}

If the shale were more than 3 million years old, as we surmise from its weathering, then it would have to have survived a number advance-retreat cycles of the Ross Ice Sheet, all of which would have covered the area with ice with little effect on the topography, apart from the deposition of thin tills as they retreated. However, the deposit must have formed subsequent to the uplift that raised the mouth of Wright Valley to its present elevation of $270 \mathrm{~m}$.

The proximity of the deposit to present sea levels (within $\sim 60 \mathrm{~m}$ ) suggests that the area has experienced only slight uplift since its formation. If the incoherent Golden Shale deposits had been below sea level they would very likely have been removed as they passed through the wave washed zone during uplift to its present elevation

Gleadow and Fitzgerald (1987) have shown that some 5 $\mathrm{km}$ of uplift has taken place along the Transantarctic mountain front since the Late Cretaceous, at an average rate of $\approx 100 \mathrm{~m} / \mathrm{Ma}$ at the zone of maximum uplift about $20-30$ $\mathrm{km}$ inland from the coast. In contrast, there has been considerable subsidence in the Ross Sea area. Between the zone of maximum uplift and the coast a number of step faults are known to exist and it is possible that the coastal 
zone, including the Marble Point-Gneiss Point region, has remained stable for a very long time, indicating that there has been very little uplift following that which caused the sea to retreat from the Wright Fiord.

\section{Conclusions}

The Golden Shale deposit at Gneiss Point is a chemical deposit comprised almost entirely of the zeolite phillipsite. It was formed by alteration of a volcanic ash, which fell in an alkaline saline lake that was probably ice-marginal to an expanded Ross Ice Shelf.

The ash is tentatively correlated with one which fell in the region about 3 million years ago and which probably originated from the Mt Discovery area. The occurrence of the phillipsite deposit is consistent with other weathering features in the Marble Point area which also support a considerable age for the landscape.

The state of preservation of the Golden Shale deposit and its geomorphic situation indicates that the area has not been subjected to much glacial or submarine erosion since its formation, and this implies a considerable degree of preservation of the landscape. As the Golden Shale occurs within $60 \mathrm{~m}$ of sea level, its presence suggests that uplift rates of the Transantarctic Mountains over the last 3 million years may have been negligible. In the event of younger ash showers being identified in the McMurdo Sound region or datable material being found within the Shale then the time scale for the events discussed here may become shorter

Acknowledgements. The authors acknowledge the Foundation for Research, Science and Technology and the New Zealand Lottery Grants Board for financial assistance and the New Zealand Antarctic Programme for logistic support. We also acknowledge the help of Warren Dickinson and Jim Bockheim who reviewed the manuscript and Peter Barrett, the co-editor.

\section{References}

Barrett, P.J., C.J Adams, C.J McIntosh, C.C. Swisher and G.J Wilson (1992), Geochronological evidence supporting Antarctic deglaciation three million years ago, Nature, 359, 816-818.

Campbell. I.B. and G.G.C. Claridge (1975), Morphology and age relationships of Antarctic soils, in Quaternary Studies, edited by R. P. Suggate and M. M. Cresswell, Roy. Soc. N. Z. Bull, 13, 83-88.

Campbell, I.B., G.G.C. Claridge and M.R Balks (1992), The properties and genesis of cryosols at Marble Point, McMurdo Sound region, Antarctica, in Cryosols: the effect of cryogenesis on the processes and peculiarities of soil formation, edited by D. A. Gilchinsky, Pushchino, Russian Academy of Sciences, 59-66.

Claridge, G.G.C. and I.B. Campbell (1974), Presence of halloysite as an indication of volcanic ash in the McMurdo sound region, Antarctica, N.Z. J. Geol. Geophys., 17, 579-585.

Claridge, G.G.C. and I.B. Campbell (in press), Zeolites in Antarctic Soils: examples from Coombs Hills and Marble Point, Geoderma.

Gleadow, A.J.W. and P.G. Fitzgerald (1987), Uplift history and structure of the Transantarctic Mountains: new evidence from fission track dating of basement apatites in the Dry Valleys area, southern Victoria Land, Earth and Planetary Science Letters, 2, 1-14.

Goldberg, E.D. and G.O.S. Arrhenius (1958), Chemistry of Pacific pelagic sediments, Geochimica et Cosmochimica Acta, 13, 153-212.

Gunn, B.M.,and G. Warren (1962), Geology of Victoria Land between the Mawson and Mulock Glaciers, N.Z. Geol. Surv. Bull., 71, 133-135.
Hall, B. L., G. H., Denton., D.R. Lux, and J.G. Bockheim (1993), Late Tertiary Antarctic paleeoclimates and ice-sheet dynamics inferred from surficial deposits in Wright Valley, Geografisker Annaler 75A, 239-267.

Hall, B.L., G.H. Denton, D.R Lux, and C.H.Hendy (2000), Evidence from Taylor Valley for a grounded ice sheet in the Ross Sea, Antarctica, Geografisker Annaler, 82A, 275-303.

Harrington, H.J. (1958), Nomenclature of rock units in the Ross Sea region, Nature, 182, 290.

Hay, R.L. (1964), Phillipsite of saline lakes and soils, Amer. Min., 49, 1366-1387.

Kelly, W.C. and J. Zumberge (1961), Weathering of a quartz diorite at Marble Point, McMurdo Sound, Antarctica, J.Geol., 69, 433-446.

Linkletter, G.O. (1974), Authigenic phillipsite in lacustrine sediments, Taylor Valley, Antarctica, N. Z. J. Geol.. Geophys., 17, 603-609.

Marchant, D.R., G.H. Denton and C.C Swisher (1993a), MiocenePliocene-Pleistocene history of Arena Valley, Quartermain Mountains, Antarctica, Geografisker Annaler, 75A, 269-302.

Marchant, D.R., G.H. Denton, D.E. Sugden and C.C. Swisher (1993b), Miocene glacial stratigraphy and landscape evolution of the western Asgard Range, Antarctica, Geografisker Annaler, 75A, 303-330.

Mariner, R.H. and R.C. Surdam,. (1970), Alkalinity and formation of zeolites in saline alkaline lakes, Science, 170, 977-980.

Metcalf and Eddy, Engineers (1958), Report on study of feasibility of construction of an airfield in the Gneiss Point-Marble Point area, McMurdo Sound, Antarctica, Appendix B to Airfield Construction feasibility study, Marble Point, Antarctica, by Construction Battalion Reconnaissance Unit, Bureau of Yards and Docks, U.S. Navy, Washington D.C.

Nichols, R L. (1968), Coastal geomorphology, McMurdo Sound, Antarctica, J. Glaciology, 7, 449-478.

Shacat, J.A., W.J Green, E..H. Decario and S. Newell (2004), The geochemistry of Lake Joyce, McMurdo Dry Valleys, Antarctica, Aquatic Geochemistry 10, 325-357.

Shirtcliffe, T.G.L. (1965), Lake Bonney, Antarctica: cause of the elevated temperatures, J. Geophys. Res., 69, 5327-5268

Webster, J.G., K.S. Webster and I. Hawes (1997), Trace metal transport and speciation in Lake Wilson, a comparison with Lake Vanda, in Ecosystems processes in Antarctic Ice-free Landscapes, edited by W.B. Lyons, C. Howard-Williams and I. Hawes, pp. 211-230, Balkema, Rotterdam. 